\title{
Climate change impacts and adaptation among smallholder farmers in Central America
}

\author{
Celia A. Harvey ${ }^{1 *} \mathbb{0}$, Milagro Saborio-Rodríguez ${ }^{2,3}$, M. Ruth Martinez-Rodríguez', Barbara Viguera², \\ Adina Chain-Guadarrama4, Raffaele Vignola ${ }^{2,5}$ and Francisco Alpizar ${ }^{2}$
}

\begin{abstract}
Background: Smallholder farmers are one of the most vulnerable groups to climate change, yet efforts to support farmer adaptation are hindered by the lack of information on how they are experiencing and responding to climate change. More information is needed on how different types of smallholder farmers vary in their perceptions and responses to climate change, and how to tailor adaptation programs to different smallholder farmer contexts. We surveyed 860 smallholder coffee and basic grain (maize/bean) farmers across six Central American landscapes to understand farmer perceptions of climate change and the impacts they are experiencing, how they are changing their agricultural systems in response to climate change, and their adaptation needs.
\end{abstract}

Results: Almost all (95\%) of the surveyed smallholder farmers have observed climate change, and most are already experiencing impacts of rising temperatures, unpredictable rainfall and extreme weather events on crop yields, pest and disease incidence, income generation and, in some cases, food security. For example, $87 \%$ of maize farmers and $66 \%$ of coffee farmers reported negative impacts of climate change on crop production, and $32 \%$ of all smallholder farmers reported food insecurity following extreme weather events. Of the farmers perceiving changes in climate, $46 \%$ indicated that they had changed their farming practices in response to climate change, with the most common adaptation measure being the planting of trees. There was significant heterogeneity among farmers in the severity of climate change impacts, their responses to these impacts, and their adaptation needs. This heterogeneity likely reflects the wide diversity of socioeconomic and biophysical contexts across smallholder farms and landscapes.

Conclusions: Our study demonstrates that climate change is already having significant adverse impacts on smallholder coffee and basic grain farmers across the Central American region. There is an urgent need for governments, donors and practitioners to ramp up efforts to help smallholder farmers cope with existing climate impacts and build resiliency to future changes. Our results also highlight the importance of tailoring of climate adaptation policies and programs to the diverse socioeconomic conditions, biophysical contexts, and climatic stresses that smallholder farmers face.

Keywords: Adaptation strategies, Climate change, Coffea arabica, Ecosystem-based Adaptation, Smallholder farmers, Zea mays

\footnotetext{
*Correspondence: celiaharvey@stanfordalumni.org

${ }^{1}$ Conservation International, 2011 Crystal Drive Suite 500, Arlington, VA

22202, USA

Full list of author information is available at the end of the article
} 


\section{Background}

Climate change poses a significant threat to smallholder farmers and threatens to undermine global progress toward poverty alleviation, food security, and sustainable development $[1,2]$. Globally, there are an estimated 475 million smallholder farmers cultivating less than 2 ha of land [3], many of whom are poor, experience food insecurity, and live in highly precarious conditions [4, 5]. Smallholder farmers are highly vulnerable to climate change because most depend on rain-fed agriculture, cultivate marginal areas, and lack access to technical or financial support that could help them invest in more climate-resilient agriculture $[4,6,7]$.

While there is growing evidence of the vulnerability of smallholder farmers to climate change $[5,8]$ and increased interest in ensuring food security under climate change $[1,2]$, adaptation efforts are still hindered by the lack of information on how smallholder farmers are experiencing and responding to climate change. Policy makers, donors, and practitioners interested in developing policies, institutional responses, and strategies for smallholder farmer adaptation need detailed, contextspecific information on what climate change impacts smallholder farmers are experiencing and whether (and how) they are adapting their management strategies to deal with these impacts $[9,10]$. In addition, more information is needed on how smallholder farmer vulnerability and responses vary across different farming systems and socioeconomic conditions.

Understanding the impacts of climate change on smallholder farmers and developing appropriate adaptation strategies are critical issues in Central America, a region where small-scale agriculture is central to economic development, food security, and local livelihoods [11]. There are an estimated 2.3 million smallholder farmers in Central America [12], many of whom farm on steep lands with thin soils, are poor, and suffer seasonal food insecurity [13-15]. Two common smallholder farming systems in the region are basic grain (maize and beans) and small-scale coffee production. There are an estimated one million smallholder farmers growing maize and beans for subsistence and local consumption [16]. Many smallholder farmers also cultivate coffee, an export crop that is a significant contributor to agricultural GDP and accounts for employment of an estimated 4 million across the region [17]. Both maize and coffee production are of a significant cultural importance in the region $[18$, 19].

Smallholder coffee and basic grain farmers are highly vulnerable to climate change as their crops are sensitive to rising temperatures and changing rainfall patterns. Rising temperatures are known to negatively affect coffee growth, flowering, fruit set, and bean quality [20, 21].
Similarly, high temperatures and drought conditions have negative impacts on biomass production, flowering, and yields of maize and beans [16]. Since smallholder farmers in Central America depend entirely on rain-fed agriculture, they are vulnerable to extended droughts, irregular rainfall patterns, and extreme rain events [18, 22, 23] which can significantly reduce yields and exacerbate food insecurity and poverty. For example, a 3-year drought (2014-2016) in the dry Pacific region of Central America resulted in 1.6 million people becoming food insecure and 3.5 million requiring humanitarian assistance [24]. Hurricanes have had significant impacts on smallholder farmer livelihoods in recent years, with strong winds and torrential rainfall destroying coffee plantations and 'milpas' (the small fields where farmers cultivate basic grains), causing leaves, flowers, and coffee cherries to drop from coffee plantations, and resulting in a significant crop damage and even crop failure [25-27]. In addition, many farmers are routinely affected by hurricane damage to roads, bridges, and farm infrastructure [25, 28], which disrupts crop harvest, processing, and transportation. For example, in 2005 Hurricane Stan resulted in the loss of $20 \%$ of the coffee harvest (worth US 4 million) in the Pacific region of Guatemala alone [29].

The impacts of climate change on smallholder agriculture are likely to intensify in future years, as climate models project rising temperatures, more erratic rainfall, and a potential increase in the intensity and/or frequency of extreme weather events [30,31]. Recent studies suggest that by 2025 climate change may reduce bean production in Central America by more than $20 \%$ and maize yields by as much as $15 \%$ in Honduras, El Salvador, and Nicaragua [16]. In addition to direct impacts on crop production, climate change will likely alter the areas suitable for smallholder production across the region. Crop suitability models suggest that $40 \%$ or more of the current coffee areas in Nicaragua, Costa Rica, and El Salvador will likely lose suitability for coffee production by 2050, as lower elevations become suboptimal for coffee production [32]. Changing climatic conditions may also indirectly affect crop production by altering the incidence and severity of pest and disease outbreaks. The recent coffee leaf rust (Hemileia vastatrix) outbreak in 2012 and 2013, which had major economic and social impacts across the region, is likely to have been caused, in part, by changing climatic conditions and, in part, by poor management resulting from high input prices and low coffee prices [33]. The coffee leaf rust outbreak decimated the region's coffee production, affecting $51.2 \%$ of the cultivated coffee area, causing the loss of $>264,000$ jobs, and resulting in economic losses of 479.2 million USD [34].

Policy makers across Central America are increasingly aware of the urgency of helping smallholder farmers 
become more resilient to climate change [35-37]; however, they lack the necessary information on how farmers are being impacted by climate change and how they could be best supported. A recent survey of Central American policy makers reported that the lack of scientific information on climate change impacts on smallholder farmers is a major constraint to the development of agricultural adaptation policies [10]. While the scientific literature on climate change impacts on smallholder farmers has rapidly expanded in recent years [e.g., 18, 38-40], there is still little information on how climate change impacts and adaptation strategies vary across different smallholder farming systems and landscapes and the extent to which adaptation strategies need to be tailored to different smallholder contexts. There is also a lack of information on how smallholder maize and bean farmers in Central America are being affected by climate change (but see 40, 41 for information from Mexico), despite their importance for food security and poverty alleviation efforts.

To inform climate change adaptation planning for smallholder farmers, we surveyed smallholder farmers in 6 Central American landscapes to examine whether farmers perceive changes in climate, how they are being impacted by climate change, whether and how they are changing their agricultural systems to cope with or adapt to climate change impacts, and what adaptation support they require from government institutions. We also explored how climate change impacts and farmer responses varied across farming systems and landscapes. Our study provides policy-relevant information that is needed for developing robust and effective adaptation strategies for smallholder farmers across the region and mainstreaming smallholder farmer adaptation into climate change and sustainable development policies. It also provides important insights into the extent to which strategies for smallholder farmer adaptation need to be tailored for different socioeconomic and biophysical contexts.

\section{Methods}

\section{Study landscapes}

We explored perceptions of climate change, climate change impacts on crop production, and adaptation strategies with smallholder farmers located in 6 Central American landscapes (Turrialba and Los Santos in Costa Rica, Choluteca and Yoro in Honduras, and Chiquimula and Acatenango in Guatemala, Fig. 1) that are typical

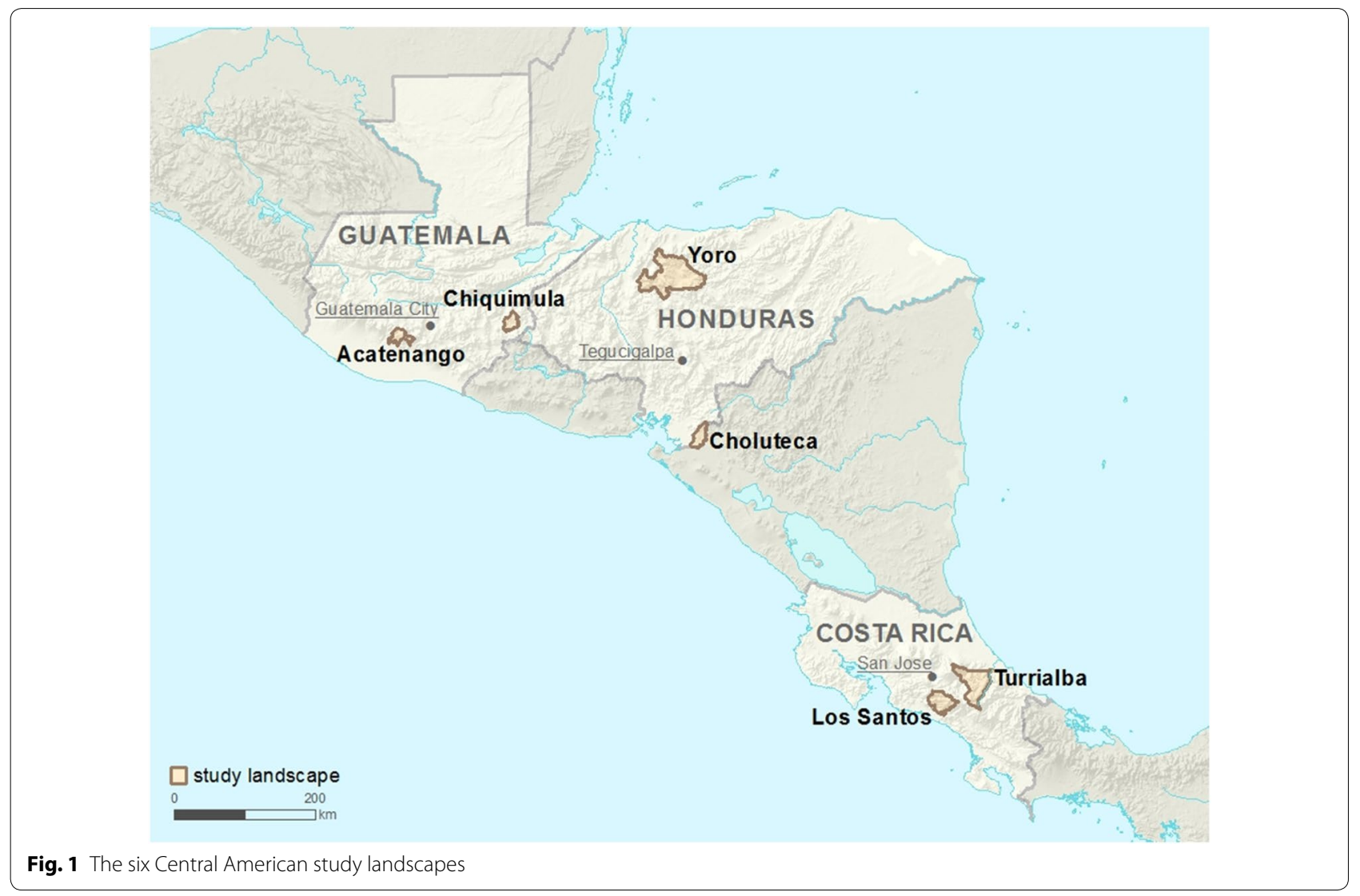


of smallholder farmer landscapes in the region. The six landscapes were selected on the basis that they (a) were dominated by smallholder farming systems, (b) had coffee (Coffee arabica) and/or basic grain production (beans (Phaseolus vulgaris) and maize (Zea mays)) as the predominant agricultural land use, and (c) had farming communities with low adaptive capacity to climate change. We focused our study on coffee and basic grains as these the two most common types of smallholder systems in the region [39]. We characterized landscapes as having low adaptive capacity using expert mapping interviews, validation workshops, and expert online surveys, in which experts from the region characterized landscapes based on 20 variables (representing natural, human, social, physical, and financial capital) that contributed to farmer adaptive capacity (see [6] for details). The Turrialba and Los Santos landscapes are dominated by smallholder coffee production, Choluteca is dominated by basic grain production, while the remaining landscapes (Yoro, Chiquimula, and Acatenango) include a mix of coffee and basic grain production. Key characteristics of the landscapes, farms, and farmers surveyed can be found in Table 1.

\section{Farmer surveys}

In each of the six landscapes, we randomly selected smallholder farmers to be interviewed about climate change impacts, responses, and adaptation needs. The sampling method varied across countries due to differences in the availability of information on farmer populations in each country, but in all cases, the selection of farmers was random. In the Costa Rican landscapes, we selected farmers randomly from an existing list of coffee farms from the 2003-2006 coffee census [42]. In the Guatemalan and Honduran landscapes, we generated a sampling frame by using remote sensing imagery to detect household roofs and then randomly sampling households from this list of potential farms. In total, we sampled 860 randomly selected farmers (115-155 farmers per landscape). To ensure our sample size consisted of only smallholder farmers, we included only farmers who self-identified as smallholder farmers and whose farm area was within two standard deviations of the mean of the sampled population.

To document farmer perceptions of climate change, perceived climate change impacts, and adaptation strategies, we implemented a detailed household survey that collected information on farm characteristics, farmer and household socioeconomic characteristics, land use, farm management practices, farmer perceptions of climate change, climate change impacts, and farmer adaptation strategies. The survey was designed to allow us to establish causal links between farmer perceptions of climate change and perceptions of climate change impacts with the adaptation measures they had implemented. For example, we first asked farmers whether they had perceived changes in temperature over the last decade. If they responded positively, we then asked them about any perceived impact from the change in temperature on their crop production, and what farm management changes, if any, they had made to address these impacts. With this approach, we were able to distinguish adaptation decisions (i.e., decisions to adapt farm management practices in response to climate change) from the myriad of decisions taken by the farmer every day in response to other issues not related to climate change (such as fluctuations in coffee prices). The survey was piloted in the field prior to data collection and underwent an ethics review before implementation. Surveys were administered in the field by a team of enumerators who underwent formal training. For a subset of 300 randomly chosen farmers (50 per landscape), we also asked follow-up questions about what adaptation support they required.

All data were collected in handheld tablets using SurveyCTO software (www.surveycto.com), to minimize data entry errors. Surveys were conducted with the household head or family member in charge of the farm at the farmer's house or on the farm. Surveys took approximately $1 \mathrm{~h}$ to complete. All surveys were conducted between April and September 2014.

\section{Data analysis}

We used descriptive statistics to summarize the main trends in data relating to farmer perceptions of climate change, perceived impacts, and adaptation measures implemented in each landscape. We also used analysis of variance to compare means across the 6 landscapes and explore landscape-specific differences. In some cases, we analyzed data for coffee farmers, maize farmers, and bean farmers separately, to explore potential differences in perceptions, impacts, or adaptation strategies across farmers with different farming systems. In these instances, we classified 'coffee farmers' as all farmers who were growing and selling coffee $(n=485)$, 'maize farmers' as those growing maize on their land $(n=490)$, and 'bean farmers' as those who grow beans $(n=383)$. Of the 860 farmers, 129 farmers grew both coffee and basic grains on their farms. These farmers were included in both the coffee and basic grain categories in the analyses comparing different cropping systems. In the Turrialba and Los Santos landscapes, the number of farmers growing beans and maize present was insignificant $(n<10)$, so we opted not to report data for these two types of farmers in these landscapes. There were no coffee farmers in the Choluteca landscape, so no data on coffee farmers are 


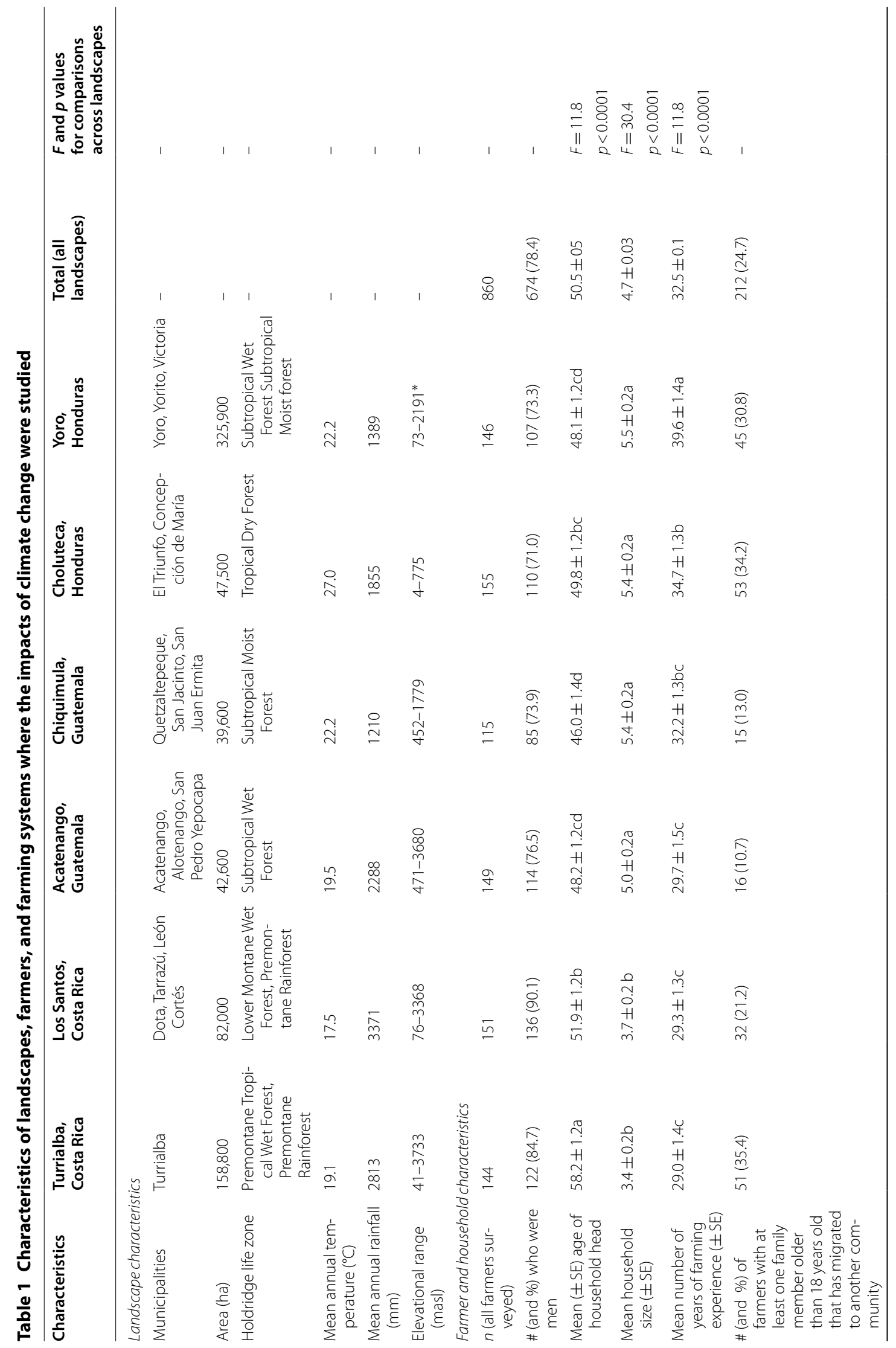




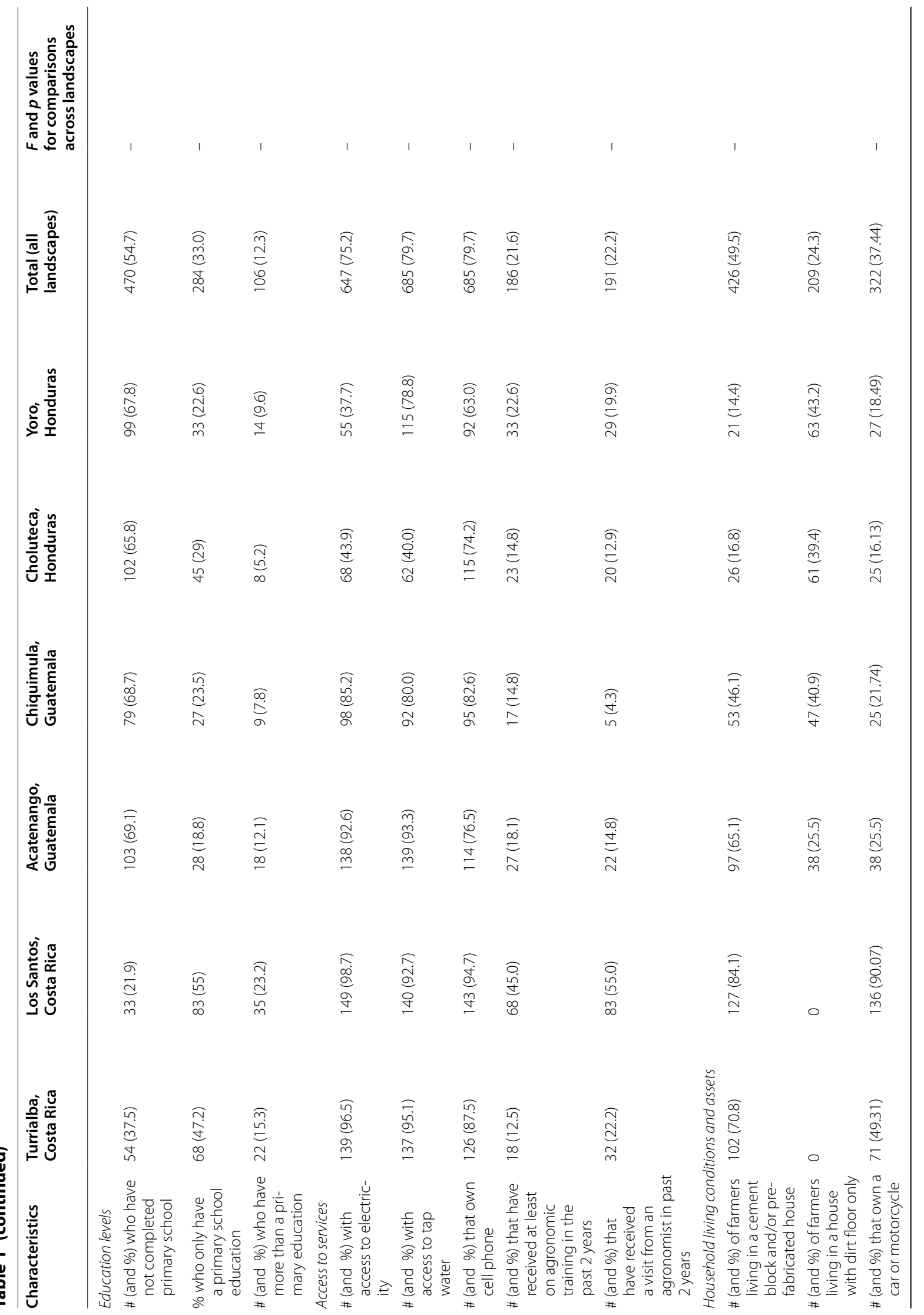




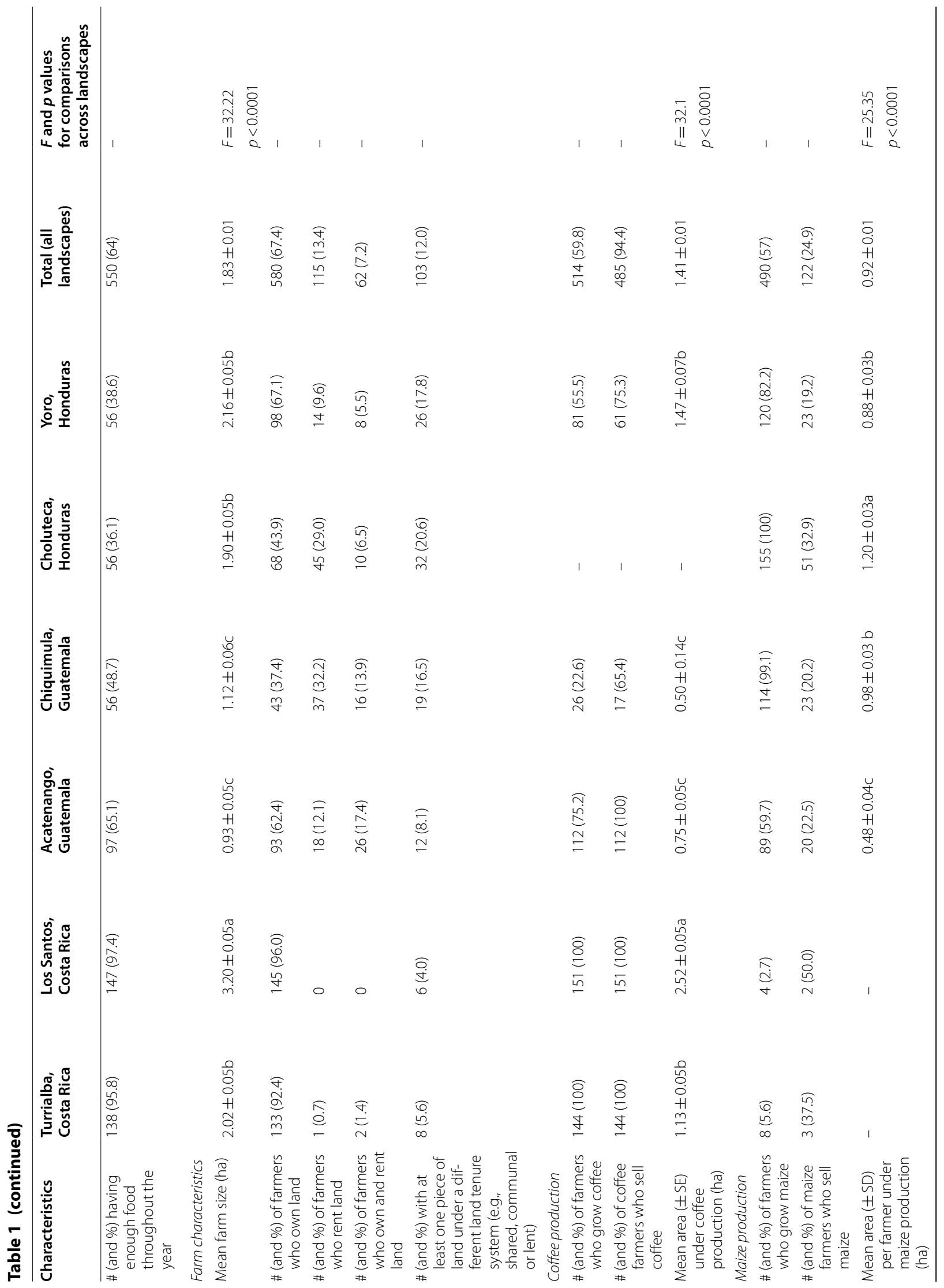




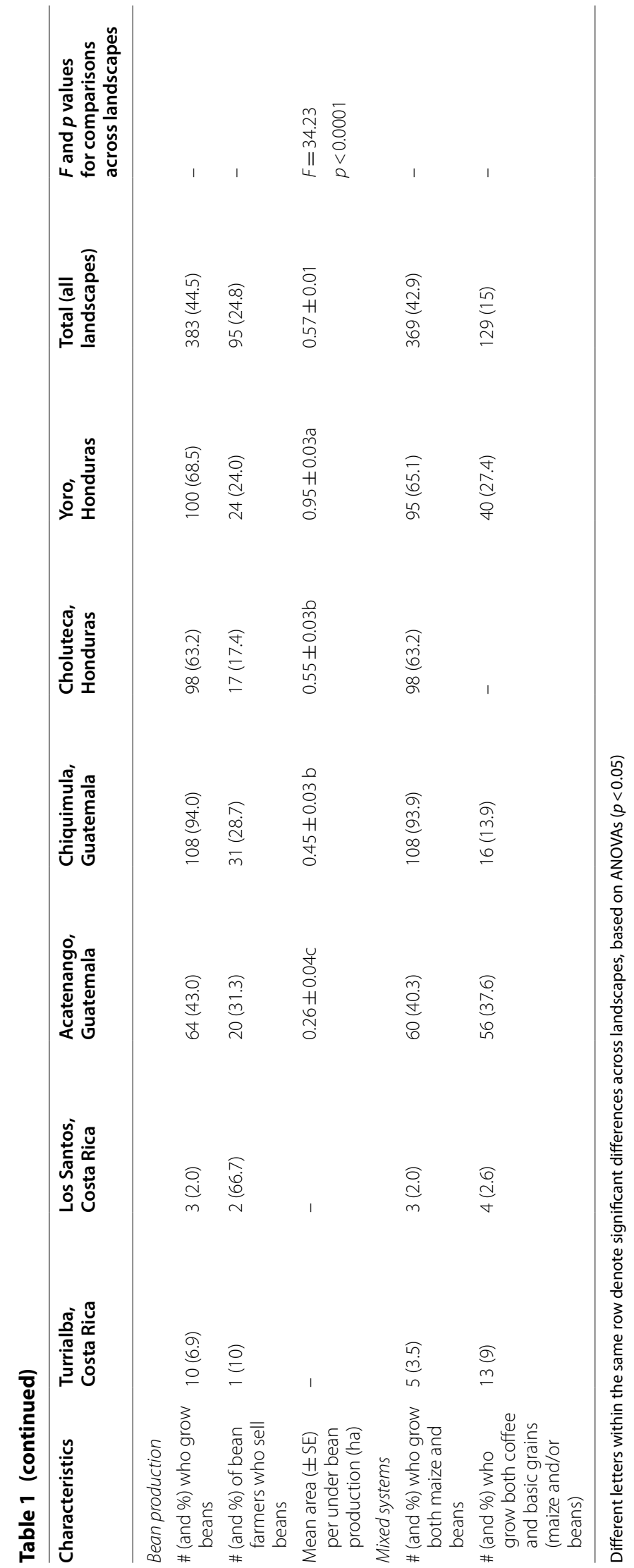


reported for this landscape. All analyses were done using the statistical package InfoStat [43].

\section{Results}

\section{Characteristics of smallholder farmers and farms}

We interviewed 860 smallholder farmers, of whom 674 (78.4\%) were men. The mean age of the farmers was $50.5( \pm 0.5 \mathrm{SE})$ years old, and they had an average of $32.5( \pm 0.1)$ years of farming experience. The farmers had a mean of $4.7 \pm 0.03$ family members, small farms (mean of $1.83 \pm 0.01 \mathrm{ha}$ ), and low levels of education, with $54.7 \%$ lacking a primary school education (Table 1 ). Many lacked access to electricity, tap water, cell phones and transportation, and a subset reported being food insecure. Few reported having access to extension support or agricultural training events. However, there were significant differences across smallholder farmers in different landscapes. For example, Costa Rican farmers generally had higher education, higher food security, and greater access to services than farmers in other countries. Almost all farmers (>92\%) in the Costa Rican landscapes owned the land they cultivated, while in the remaining countries, many farmers rented part of the land they cultivate or had alternative tenure arrangements.
Of the farmers interviewed, 59.8\% had coffee plantations, with an average coffee area of 1.41 ha $( \pm 0.01)$. Of the farmers growing coffee, $94 \%$ sold their coffee production. Fifty-seven percent of the farmers grew maize, with an average area of 0.92 ha $( \pm 0.01)$. Most maize production was for home consumption, with less than a quarter of farmers selling their maize production. Forty-four percent of the farmers grew beans, with an average bean area of 0.57 ha $( \pm 0.01)$. Like maize production, most bean production was for home consumption and only $24.8 \%$ of farmers producing beans sold their produce. Of the 860 farmers, $15 \%$ of the farmers grew both coffee and basic grains (either maize and/or beans), and $42.9 \%$ grew both maize and beans.

\section{Farmer perceptions of climate change and climate change impacts}

Ninety-five percent of all farmers surveyed reported that they have perceived changes in local climate over the last decade. Of those who perceived the climate to be changing, $96.3 \%$ reported changes in temperature and $94.6 \%$ in rainfall (Table 2). The most commonly reported change among those farmers perceiving changes in overall temperature was temperature rise (mentioned by $96.1 \%$ of farmers). Among farmers perceiving changes in overall

Table 2 Percent of smallholder farmers reporting changes in climate over the last decade

\begin{tabular}{|c|c|c|c|c|c|c|c|}
\hline $\begin{array}{l}\% \text { of farmers perceiving changes } \\
\text { over the last decade }\end{array}$ & $\begin{array}{l}\text { Turrialba, } \\
\text { Costa Rica }\end{array}$ & $\begin{array}{l}\text { Los Santos, } \\
\text { Costa Rica }\end{array}$ & $\begin{array}{l}\text { Acatenango, } \\
\text { Guatemala }\end{array}$ & $\begin{array}{l}\text { Chiquimula, } \\
\text { Guatemala }\end{array}$ & $\begin{array}{l}\text { Choluteca, } \\
\text { Honduras }\end{array}$ & $\begin{array}{l}\text { Yoro, } \\
\text { Honduras }\end{array}$ & $\begin{array}{l}\text { Total } \\
\text { (across } 6 \\
\text { landscapes) }\end{array}$ \\
\hline \multicolumn{8}{|l|}{ Overall changes noted } \\
\hline n (all farmers surveyed) & 144 & 151 & 149 & 115 & 155 & 146 & 860 \\
\hline Overall change in climate & 98.6 & 97.4 & 92.0 & 96.5 & 93.6 & 94.5 & 95.4 \\
\hline$n$ (farmers perceiving change in climate) & 142 & 147 & 137 & 111 & 145 & 138 & 820 \\
\hline Overall change in temperature & 97.2 & 98.6 & 96.4 & 91.0 & 98.6 & 94.9 & 96.3 \\
\hline Overall change in rainfall & 95.1 & 95.9 & 92.7 & 99.1 & 96.6 & 89.1 & 94.6 \\
\hline \multicolumn{8}{|l|}{ Specific perceived changes in temperature } \\
\hline $\begin{array}{l}n \text { (farmers perceiving changes in tempera- } \\
\text { ture) }\end{array}$ & 138 & 145 & 132 & 101 & 143 & 131 & 790 \\
\hline The temperature has increased & 97.1 & 96.6 & 96.2 & 94.1 & 95.8 & 96.2 & 96.1 \\
\hline Night and day are both warmer & 2.9 & 0.7 & 21.2 & 15.8 & 21.0 & 6.9 & 11.1 \\
\hline $\begin{array}{l}\text { Cool season and warm season are both } \\
\text { warmer }\end{array}$ & 4.4 & 8.3 & 8.3 & 8.9 & 4.9 & 8.4 & 7.1 \\
\hline \multicolumn{8}{|l|}{ Specific changes in rainfall noted } \\
\hline$n$ (farmers perceiving changes in rainfall) & 135 & 141 & 127 & 110 & 140 & 123 & 776 \\
\hline Less rain falls in a year & 66.7 & 66.7 & 46.5 & 85.5 & 90.0 & 56.1 & 68.6 \\
\hline When the rains will begin is unknown & 26.7 & 19.2 & 15.8 & 13.6 & 29.3 & 30.9 & 22.8 \\
\hline Rainfall is concentrated in a shorter period & 20.0 & 38.3 & 31.5 & 8.2 & 3.6 & 9.8 & 18.9 \\
\hline When it will rain is unknown & 20.7 & 17.7 & 22.8 & 13.6 & 18.6 & 8.9 & 17.3 \\
\hline Rainy season begins later than usual & 5.9 & 6.4 & 18.1 & 12.7 & 14.3 & 23.6 & 13.3 \\
\hline More rain falls in a year & 4.4 & 1.4 & 27.6 & 7.3 & 2.9 & 5.7 & 8.0 \\
\hline
\end{tabular}

The table shows only those changes that were reported by at least $5 \%$ of all farmers surveyed 
rainfall the most common changes included lower annual rainfall $(68.6 \%)$, and greater uncertainty in when the rains will begin (mentioned by $22.8 \%$ ). Many farmers also reported changes in the seasonality of the rainy season. Farmer perceptions of how rainfall patterns had changed differed across landscapes (Table 2).

Most smallholder farmers reported that climate change has negatively impacted their crop production, with $87 \%$ of maize farmers, $78.4 \%$ of bean producers, and $66.4 \%$ of coffee farmers reporting reduced yields (Fig. 2a). In three of the four landscapes where both basic grains and coffee are grown, a greater proportion of farmers reported impacts on maize and bean production than on coffee production. Smallholder farmers also attributed increases in pest and disease outbreaks to climate change, with $73.9 \%$ of coffee farmers, $78.4 \%$ of maize farmers, and $67.9 \%$ of bean farmers reporting climateassociated increases in crop pests and diseases over the past 10 years (Fig. 2b). However, the percent of farmers indicating climate-related disease and pest outbreaks differed across landscapes.

\section{Effects of extreme weather events on agricultural production, food security, and income}

Many farmers reported that their agricultural systems had been affected by extreme weather events during

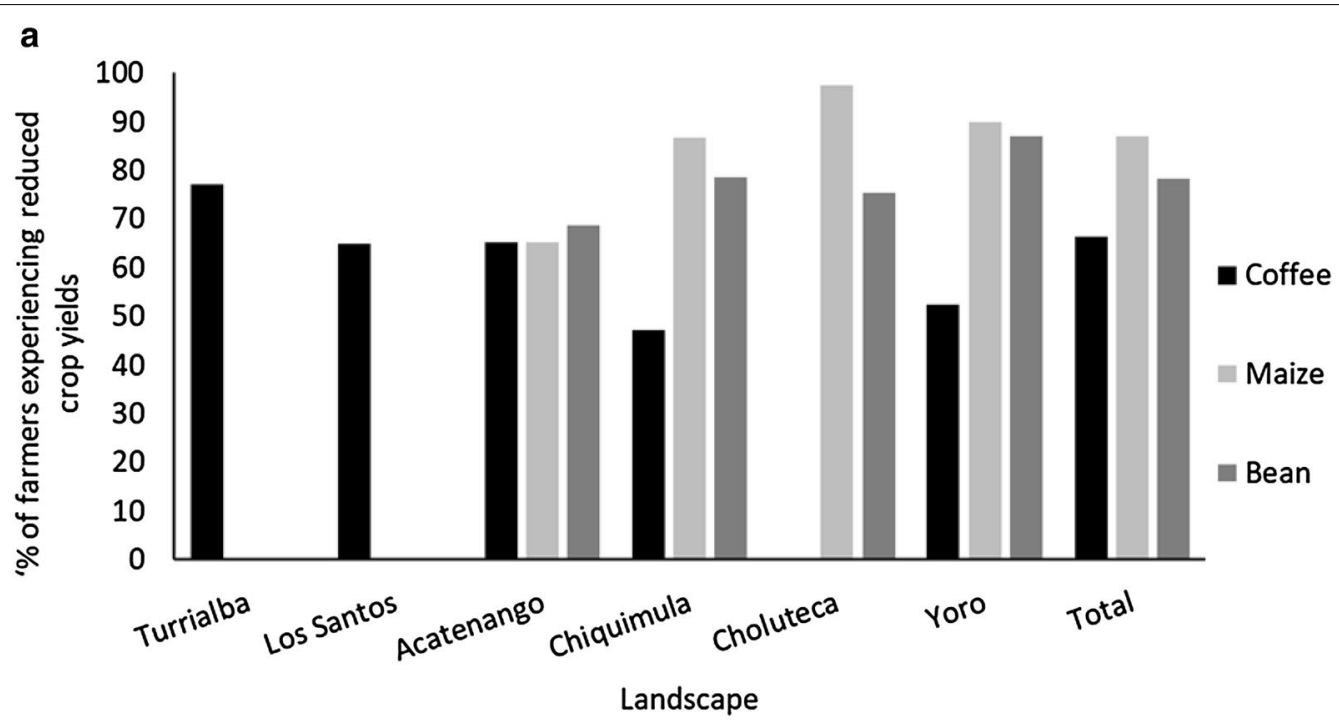

b

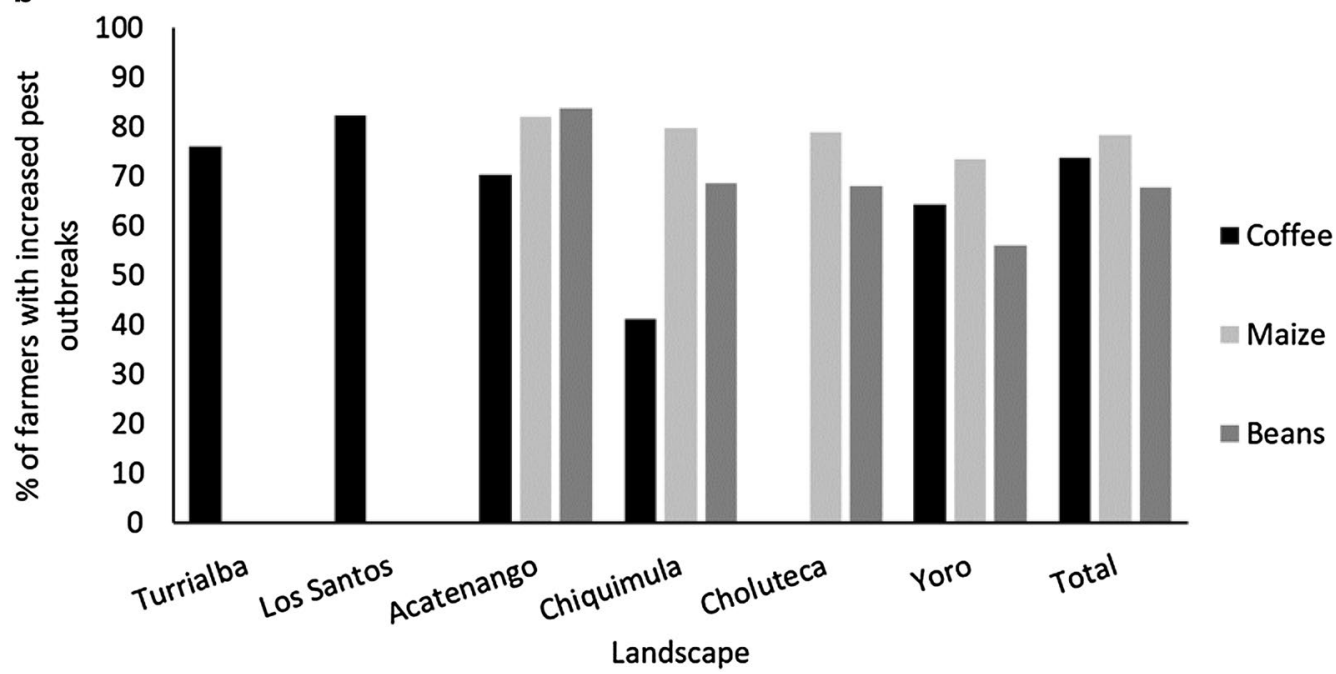

Fig. 2 Percent of farmers perceiving negative impacts of climate change on a crop yields and $\mathbf{b}$ outbreaks of pests and diseases over the last 10 years. Note that there were less than 10 maize or bean farmers surveyed in Turrialba or Los Santos, and there were no coffee farmers in Choluteca, so no data are reported for these crops in those locations in this figure or subsequent figures 
the last decade (Fig. 3a): 57.3\% reported having been impacted by droughts, $52.0 \%$ by heavy rainfall events, $32.1 \%$ by hurricanes, and $12.6 \%$ by floods. The percentages of farmers reporting these events and the main climatic stresses varied across landscapes. In Chiquimula, Choluteca, and Yoro, drought was the main climatic stress for farmers. In Acatenango, hurricanes and heavy rainfall were the main challenges, while in Turrialba and Los Santos, farmers were exposed to multiple climatic stresses.

Extreme weather events have had significant impacts on smallholder crop production: $94.6 \%$ of maize farmers, $78.8 \%$ of coffee farmers, and $77.5 \%$ of bean farmers reported that extreme weather events had negatively affected their crop yields over the last 10 years (Fig. 3b). Maize and bean farmers generally reported higher crop losses due to extreme weather events than did coffee farmers: $50.9 \%$ of all maize farmers reported losses of $>50 \%$ of their crop due to extreme weather events, and an additional $37.6 \%$ reported losses of $25-50 \%$ of their crop. Bean production was also significantly impacted, with $44.8 \%$ of farmers growing beans reporting losses of more than half their crop due to extreme weather events. In contrast, only $16.4 \%$ of farmers growing coffee reported high $(>50 \%)$ losses due to extreme weather events.

Extreme weather events have also led to increased food insecurity among smallholder farmers in some of the landscapes (Fig. 3c). Overall, 32.4\% of smallholder farmers reported food insecurity following the most severe extreme weather events; however, there were pronounced differences across landscapes, with highest food insecurity in Choluteca (affecting 63\% of farmers) and Yoro (affecting 44.5\%). In contrast, in the Costa Rica landscapes, less than $7 \%$ of farmers indicated food shortages following extreme weather events. There were also differences in food insecurity levels across different types of farmers: $47 \%$ of both maize and bean farmers indicated they had experienced food shortages following extreme weather events, compared to only $15.1 \%$ of coffee farmers.

Across the 6 landscapes, $44.5 \%$ of farmers reported experiencing decreases in household income following extreme weather events (Fig. 3d). The percent of farmers experiencing income reductions following extreme weather events was highest in the Honduran landscapes (Choluteca and Yoro). A greater proportion of maize and bean farmers (56.7\% in both cases) reported impacts on household income, compared to coffee (29.9\%); maize and bean farmers also reported more significant income reductions than coffee farmers.

\section{Adaptation strategies used by smallholder farmers}

Of the 820 farmers perceiving changes in climate, $46.1 \%$ indicated that they had changed their farming practices in response to climate change (Fig. 4). The percent of farmers changing farming practices in response to climate change was highest in the Los Santos (78.2\%) and lowest in Chiquimula (24.3\%). There were also differences in the frequency of use of adaptation strategies across different types of farmers: $58.7 \%$ of coffee farmers had made changes in response to climate change, compared to only $35.5 \%$ of basic grain farmers. On average, farmers who had changed their management practices in response to climate change had implemented an average of $1.5( \pm 0.12)$ adaptation practices.

Smallholder farmers had implemented a variety of adaptation practices, including agroforestry and restoration activities, the adoption of agroecological practices, the use of intensification, and the use of new crop varieties and technologies (Table 3). The most common practice used by both coffee and basic grain farmers was the planting of more trees on farms (reported by $48.1 \%$ of all coffee farmers who implemented adaptation measures and by $33.1 \%$ of all maize farmers who implemented adaptation measures). Among coffee farmers who had implemented adaptation practices, other common practices included applying using more pesticides, herbicides, and fungicides (17.2\%), adopting soil and water conservation practices (15.3\%), and using more fertilizers (14.8\%). Among basic grain farmers who implemented adaptation measures, other specific adaptation practices included the adoption of soil and water conservation practices (13.4\%) and changing agricultural calendars (15.7\%).

\footnotetext{
(See figure on next page.)

Fig. 3 Percent of smallholder farmers who have experienced $\mathbf{a}$ an extreme weather event, $\mathbf{b}$ reductions in crop yields, $\mathbf{c}$ food insecurity or $\mathbf{d}$ reductions in household income due to extreme weather events. For figures $\mathbf{b}$ and $\mathbf{d}$, the percentages reflect the farmer recollections of the percent of income or crop yield loss experienced following the extreme weather event that according to the farmer most affected its home, land, or parcel. Sample sizes vary across figures due to the sequencing of the survey: $\mathbf{a}$ the sample size corresponds to all 860 interviewed farmers, $\mathbf{b}$ sample size corresponds to total number or coffee $(n=287)$, maize $(n=413)$, and bean $(n=318)$ farmers indicating being affected by at least one extreme weather event and reporting general impacts on crop production; c sample size corresponds to coffee $(n=398)$, maize $(n=457)$, and bean ( $n=353$ ) farmers reporting being affected by at least on extreme event; and $\mathbf{d}$ sample size corresponds to total number or coffee ( $n=398)$, maize $(n=446)$, and bean $(n=342)$ farmers indicating being affected by at least on extreme weather event and reporting general impacts on household income
} 


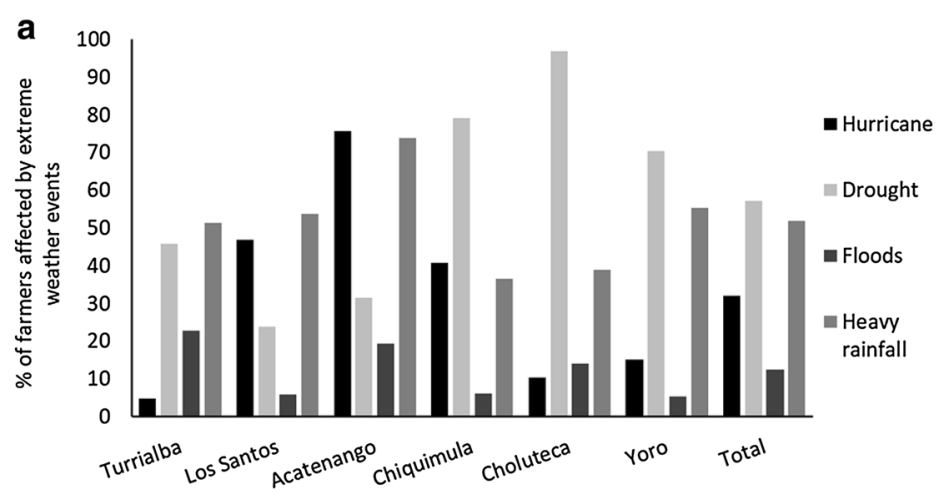

b

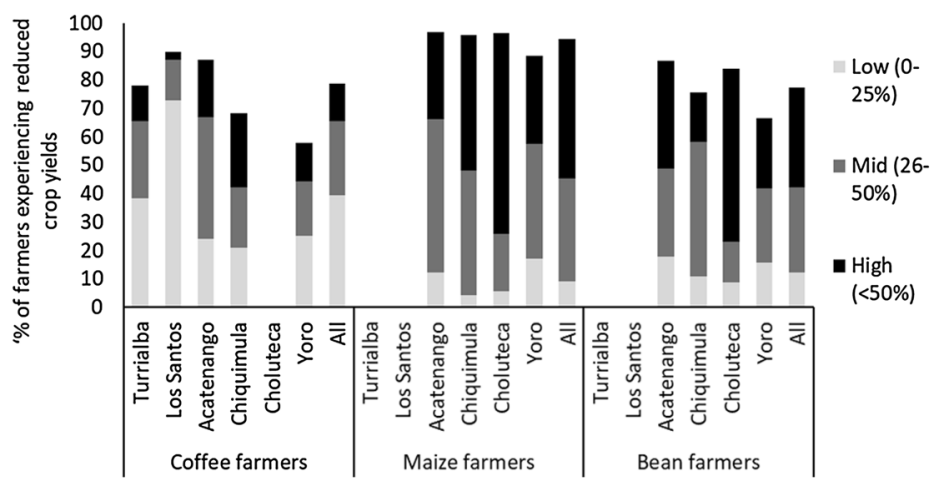

C

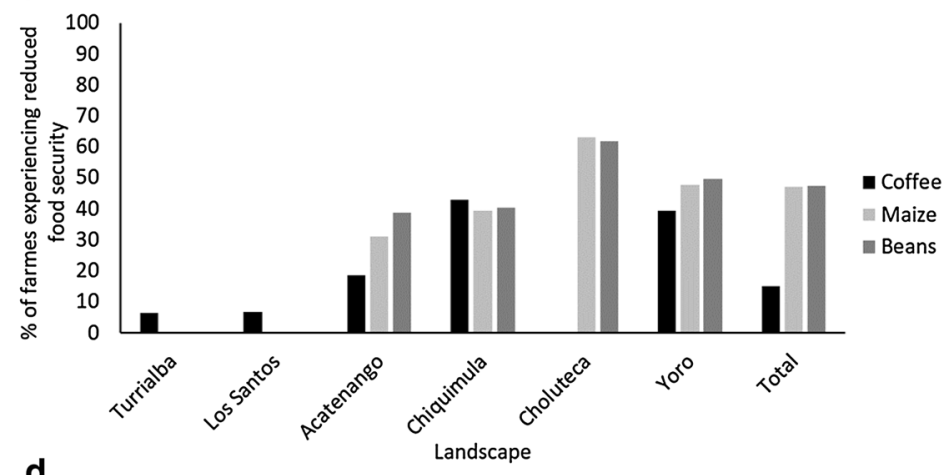

d

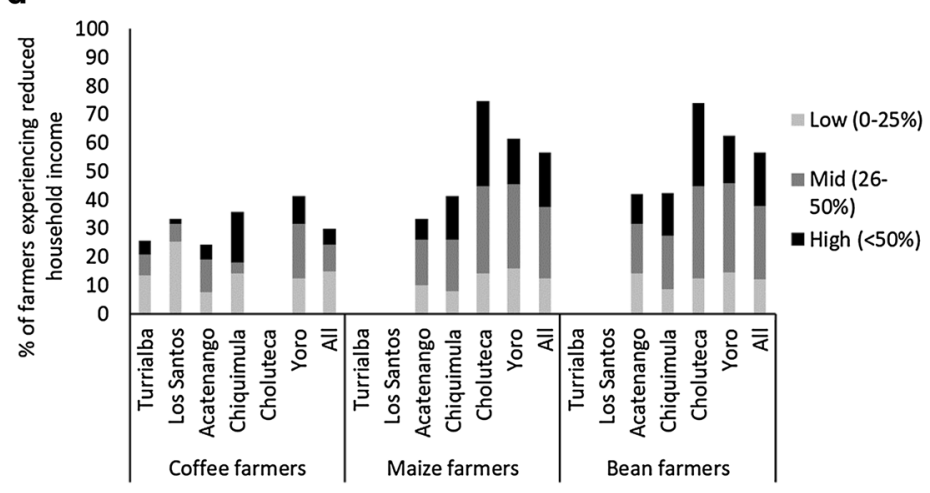




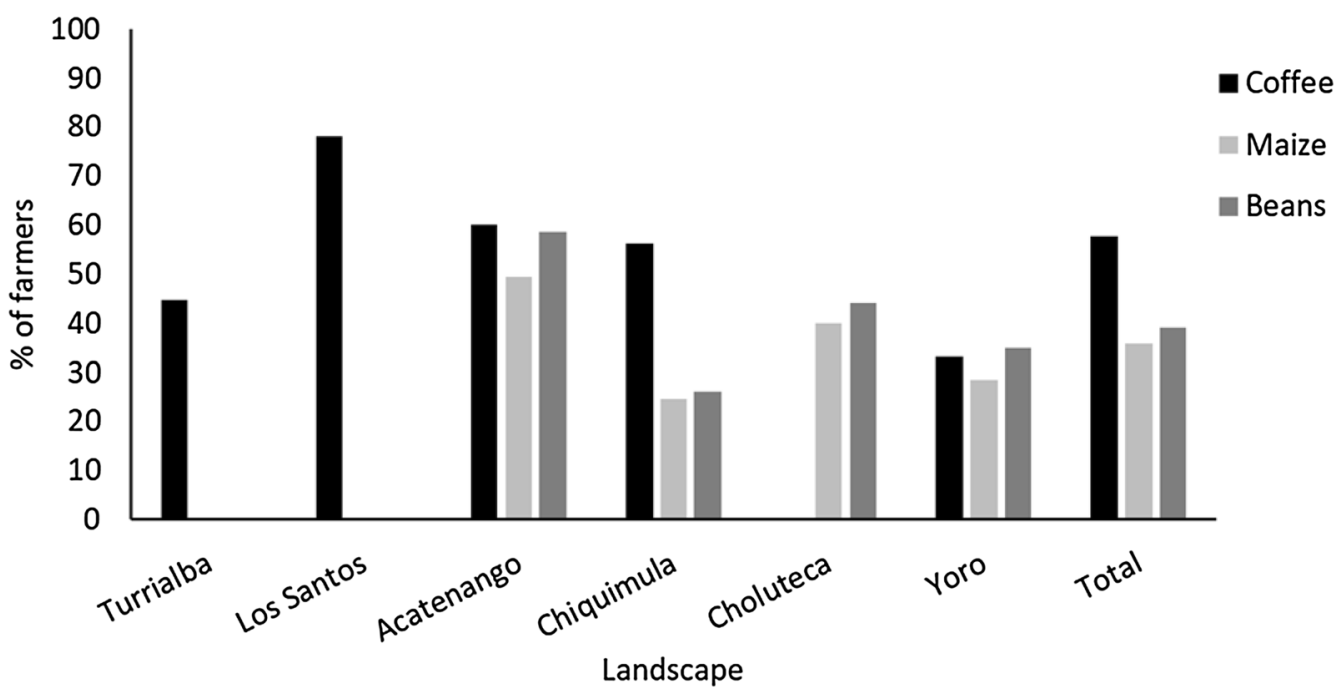

Fig. 4 Percent of smallholder farmers who have changed farming practices in response to climate change

\section{Farmer adaptation needs}

Smallholder farmers identified numerous ways in which governments, agricultural research centers, and other institutions could help them adapt to climate change (Additional file 1: Table S1). Among the subset of 188 coffee farmers who were asked about adaptation needs, the most commonly mentioned needs were the provision of fertilizers and agrochemicals (mentioned by $40.4 \%$ ), technical support (40.4\%), training (18\%), improving coffee prices and marketing (17.0\%), and providing access to finance $(14.4 \%)$. However, there were landscape-level differences in the identified needs. For example, the most commonly mentioned need by coffee farmers in the Guatemalan and Honduran sites was the provision of agrochemicals, while in the Costa Rica sites, the highest demand was for technical support.

Among the subset of 169 basic grain farmers who were asked about adaptation needs, the most commonly mentioned need was the provision of agrochemical inputs (mentioned by $84.0 \%$ ), followed by financial incentives (33.1\%), and provision of improved varieties and seeds (30.2\%). Other needs-such as technical support and training-were also mentioned, but with lower frequencies. Specific adaptation needs varied across landscapes (S1).

\section{Discussion}

Climate change perceptions, impacts, and responses of smallholder farmers

Our study indicates that climate change is already putting a significant pressure on smallholder coffee and basic grain farmers across Central America, and highlights the urgent need to build farmer resilience to sustain food security and maintain rural livelihoods under changing climatic conditions. Like studies of smallholder farmers in other developing regions [e.g., 44-47], we found that almost all of the Central American smallholder farmers surveyed had perceived changes in their local climate over the last decade, regardless of their farming system or the landscape in which they were located. The most commonly observed changes include rising temperatures, more variable rainfall, and changes in the onset and length of the rainy season. Farmers' perceptions of climate change generally mirrored historical climatic data for the region which show significant increases in mean temperatures and increases in maximum temperatures across most of Central America, but less clear trends in rainfall patterns $[31,48]$. Most farmers (87.2\%) also reported having been affected by at least one extreme weather event during the last decade, and many considered that the frequency and intensity of extreme weather events were increasing, as is also suggested by projections from climate models [30]. Smallholder farmers are keenly aware of changing climatic conditions because they plan their planting, management, and harvesting activities in response to seasonal rainfall patterns [15, 41, 49]. They also see visible impacts of extreme temperatures, droughts, or torrential rains on plant growth, flowering, coffee berry ripening, and pest and disease incidence [25, 26, 50].

Changing climatic conditions are already presenting a significant challenge to smallholder coffee and maize farmers in Central America. Across the region, most smallholder farmers attributed reductions in crop yields and changes in pest and disease outbreaks (such as coffee 


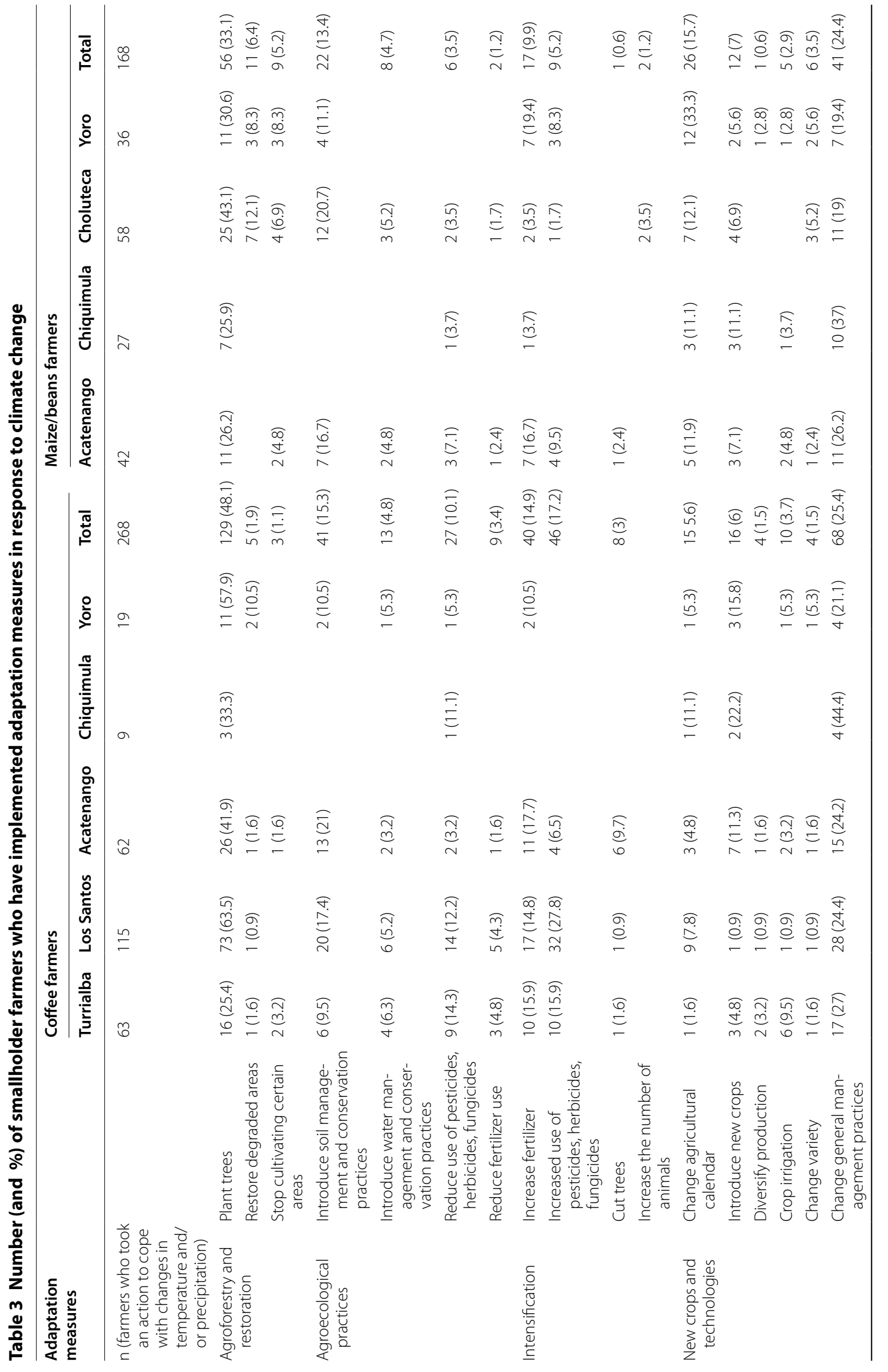




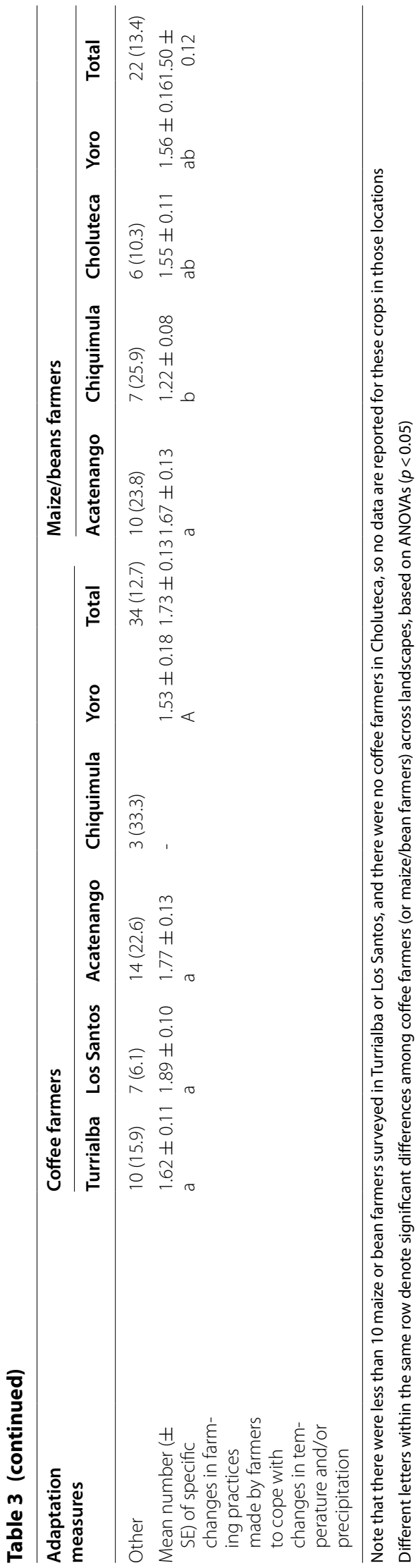


leaf rust, fall armyworm, and others) to rising temperatures and changing precipitation patterns. They also reported detrimental impacts of extreme weather events on crop yields, pest and disease incidence, household income, and, in some cases, household food security. Although the perceived impacts varied across households and landscapes, the magnitude of potential climate change impacts on smallholder farmer was significant: of the smallholder farmers who were affected by an extreme weather in the last decade, $32.4 \%$ reported being food insecure following the extreme weather event and $27.5 \%$ reported losing more than half their household income. Our study provides novel information on how climate change is affecting smallholder basic grain farmers across Central America, a group that is critical for regional food security, and strengthens the evidence based on coffee farmers are being impacted across Mesoamerica [e.g., 18, $28,38,39]$. Collectively, these results highlight the potential for climate change to have significant economic and social impacts across the region, unless action is taken to help smallholder farmers cope with and adapt to these changes.

Interestingly, although most coffee and basic grain smallholder farmers perceived climate change to be occurring and reported significant impacts on their farms and livelihoods, less than half of them had actively changed their farm management practices to minimize impacts or adapt to these changes. Even among those who did change their farm management practices in response to climate change, most had adopted only two or two practices (mean of 1.5 practices). This gap between the perceptions of climate change and implementation of adaptation measures has been noted in studies of smallholder farmers elsewhere [e.g., 18, 51, 52] and is thought to reflect their low adaptive capacity. In our study, the limited use of adaptation strategies probably reflects the fact that farmers have small plots of land, limited capital and labor, low education, and little access to finance or technical support and are therefore constrained in their ability to invest in their farms and adopt management practices which could enhance farm resiliency. In addition, some smallholder farmers (particularly maize and bean farmers in Honduras and Guatemala) have insecure land tenure and either rent the land that that they cultivate, use communal land, or share land with other farmers. Our parallel field survey of farm practices used by these smallholder farmers [53] found that smallholder farmers with insecure land tenure were less likely to have implemented adaptation strategies than those farmers who owned their land, because they were unwilling to make long-term investments in practices that yield longterm benefits. Insecure land tenure, limited capital, low education, and lack of access to financial and technical support have also been identified as key constraints to adaptation elsewhere [e.g., 6, 16, 54, 55]. The fact that farmers identified the need for government support in providing agricultural inputs, technical support, training, and access to finance further corroborates that these factors serve as constraints to farmer adaptation.

Among those smallholder farmers who implemented adaptation measures, the most common actions included planting of trees, adopting soil conservation practices, increasing fertilizer or agrochemical use, and introducing new crops. Some of these practices are considered 'Ecosystem-based Adaptation' (i.e., adaptation practices that are based on the conservation, restoration, and sustainable management of biodiversity and ecosystem services [56]) and are known to improve the longterm resiliency of smallholder farming systems [57]. For example, the incorporation of trees as shade is known to buffer extreme temperatures within fields [21, 58], mitigate the impacts of extreme weather events [59,60], and ensure the provision of ecosystem services $[61,62]$ and can therefore help enhance adaptation of farming systems. Farmers in Chiapas, Mexico, for example, planted more shade trees in their coffee plots as a response to Hurricane Stan [26]. Similarly, the planting of fruit trees has been reported as a means of reducing food insecurity of farmers under changing climatic conditions [49, 63]. However, other practices being used by smallholder farmers in our study landscapes, such as the increased use of fertilizers and agrochemicals to ensure yields under adverse climatic conditions, are resource-intensive solutions that are short-term fixes that are unlikely to contribute to climate resilience and could even be counterproductive to long-term adaptation efforts [15].

\section{Differences in climate change impacts and responses across smallholder farming systems and landscapes}

While almost all smallholder farmers perceived climate change to be happening and reported climate change impacts, farmers varied in the impacts they experienced, their use of adaptation strategies, and their adaptation needs. In general, maize and bean farmers appeared to be slightly more affected by impacts of climate change than coffee farmers, with a larger percentage of basic farmers reporting impacts of climate change on their crop production than coffee farmers. Smallholder basic grain farmers also appeared to suffer greater impacts of extreme weather events, with a greater proportion of basic grain farmers suffering food insecurity (47 vs. $15.1 \%$ of coffee farmers), and experiencing a loss in household income (56.7\% vs. $29.9 \%)$ following extreme events. In addition, the magnitude of crop loss and income losses following extreme weather events were higher among smallholder farmers. The 
higher vulnerability of basic grain farmers probably reflects the fact that these farmers tend to cultivate slightly smaller plots of land, are directly dependent on their plot for food security, are less likely to own the land they cultivate, and are often much poorer than their coffee counterparts [41, 64]. It also reflects the differential vulnerability of the agroecosystems: in the landscapes we studied, coffee is traditionally planted in agroforestry systems [53], which are more likely to endure climate change impacts than non-agroforestry systems such as basic grains $[65,66]$. Basic grain farmers are also less likely to have access to technical support than coffee farmers: only $13.1 \%$ of basic grain farmers had been visited by agronomists in the last 2 years, compared to $31.3 \%$ of coffee farmers. Whereas coffee farmers are also highly vulnerable to climate change and face many of the same constraints to adaptation, they appear to be slightly better off, as they obtain annual income from coffee production, are more integrated into markets, and are more likely to have access to some technical advice or support to cope with climate change impacts [67].

There was also heterogeneity in climate change impacts and farmer responses across the six landscapes studied. Smallholder farmers in different landscapes were exposed to different types of climatic stresses, with some farmers being most affected by droughts and others struggling with the impacts of excessive rainfall or hurricanes. There were also landscape-level differences in the percent of farmers reporting different climate change impacts and the severity of these impacts. One clear difference was the fact that smallholder farmers in Costa Rica were much less likely to be food insecure following extreme weather events than farmers in Honduras or Guatemala. Costa Rican farmers were generally better off than farmers in the surrounding countries, with higher education levels, better homes, and better access to services (communication, electricity, water), and it is likely that these characteristics improve farmers' ability to cope with climatic stresses. Another key difference was that a much higher proportion of farmers in Los Santos, Costa Rica, had adopted adaptation measures in response to climate change than in other landscapes. We suspect this is due to the presence of strong coffee cooperatives in the region (e.g., CoopeTarrazu, CoopeDota) which provide farmers with technical support and advice. While more research is needed to understand the factors that influence the use of adaptation measures by smallholder farmers, the differences among smallholder farmers cultivating different crops and living in different geographic settings point to the very specific nature of climate change impacts, the varying adaptive capacities of smallholder farmers, and the need for locally tailored adaptation solutions.

\section{Conclusions and policy implications}

Our study has several key implications for policy makers, donors, and practitioners interested in enhancing smallholder farmer resilience to climate change in the Central American region. First, our study suggests that there is an urgent need to ramp up efforts to help smallholder farmers cope with existing changes and adapt to future climatic conditions. Climate change is already having significant adverse impacts on smallholder coffee and basic grain farmers across the region and could undermine national and regional efforts to alleviate poverty, achieve food security, and enhance economic development. Facilitating smallholder farmer adaptation to climate change will require a combination of policy, technical, and research solutions, including the development of adaptation policies and programs targeted at smallholder farmers, the creation of incentives, credits, and other financing mechanisms to support farmer adaptation efforts, the development of research to identify the most effective adaptation options, and the strengthening of extension services to provide technical support to farmers on how to enhance their resilience to climate change $[10,52,53]$, among other activities. As Central American countries develop their national climate adaptation strategies and plans for achieving the UN Sustainable Development Goals, the adaptation needs of smallholder farmers merit special attention.

Second, there is a need to identify adaptation strategies that are accessible for smallholder farmers and fit their agroecological and socioeconomic contexts. A wide range of adaptation options have been proposed for helping farmers adapt to climate change. These include planting new crop varieties that are heat tolerant, drought resistant, or less susceptible to pests and diseases [38, 39], increasing fertilizer and pesticide use [52], improving water management through irrigation and water harvesting [39, 47], changing farm management practices such as changes in planting dates or crop rotations [46], adopting soil conservation practices such as live barriers, cover crops, and terracing $[64,68]$, diversifying crop production and household income sources [49, 62, 69], and restoring degraded areas and risk-prone sites [38], among others. All of these options merit inclusion in adaptation strategies. However, many of the technological adaptation strategies (such as the planting of new varieties, establishment of irrigation systems, or an increased use of fertilizers and agrochemicals) are resource-intensive and are often beyond the reach of smallholder farmers who have limited capital, family labor, and access to credit or finance [51]. Ecosystem-based Adaptation measures, such as adding trees to coffee systems to buffer the impacts of extreme weather events or diversifying crop production to reduce the risk of crop losses, may be 
more accessible to smallholder farmers as they are based on the management of existing resources $[53,57]$. Adaptation plans should therefore support a diverse menu of adaptation practices that farmers can select from and modify based on their contexts, needs, and experiences. Farmers should also be encouraged to develop adaptation strategies that combine multiple adaptation practices that together provide long-term resilience, rather than adopting individual practices which, on their own, may provide more limited adaptation benefits.

Finally, given the heterogeneity of different smallholder farmer contexts and experiences with climate change, it will be important to develop adaptation strategies that are flexible and can be tailored to specific farming contexts and climatic stresses. Adaptation strategies need to consider the diversity of farming systems, socioeconomic conditions (e.g., poverty, land tenure, food insecurity), and climatic stresses that smallholder farmers face. Emphasis should be placed on building farm resilience to both climate change and other stressors [9], and ensuring farmers can both cope with existing changes and adapt to future conditions. For smallholder farmers who are living on the edge, any efforts to increase their resiliency to climate change must begin by addressing the underlying poverty and food insecurity they face, securing access to electricity, running water and other key services, improving crop productivity and income generation, and securing land tenure [18], as these stresses make them highly vulnerable to climate change and, if unaddressed, will undermine adaptation efforts [46]. Access to disaster relief following extreme weather events, such as droughts or hurricanes, is also critical for ensuring smallholder farmers do not get trapped in poverty [67]. Once the basic needs of smallholder farmers are met and their vulnerability is reduced, emphasis can be placed on building capacity, developing knowledge networks to exchange experiences, providing technical assistance, and facilitating access to credit and finance to implement adaptation measures that enhance long-term resiliency. The design and implementation of adaptation strategies that build the resilience of smallholder farmers to climate change will be challenging, but is necessary if the region is to achieve its goals of alleviating poverty, achieving food security, and enhancing economic development.

\section{Additional file}

Additional file 1: Table S1. Percent of coffee and basic grain farmers indicating the support they need from governments, agricultural centers and other organizations to adapt to climate change.

\section{Authors' contributions}

$\mathrm{CH}, \mathrm{FA}, \mathrm{MSR}$, MRMR, and RV generated the research idea, designed the study, and developed the household survey instrument. MS, FA, and BV oversaw field data collection and organized the database. $\mathrm{AC}$ and $\mathrm{CH}$ led data analysis and interpretation. $\mathrm{CH}$ and $\mathrm{AC}$ led the writing of the manuscript. MSR, MRMR, RV, $\mathrm{BV}$ and FA contributed to the writing of the manuscript.

\section{Author details \\ ${ }^{1}$ Conservation International, 2011 Crystal Drive Suite 500, Arlington, VA 22202, USA. ${ }^{2}$ Tropical Agriculture and Higher Education Center (CATIE), Apdo 7170, Turrialba, Costa Rica. ${ }^{3}$ University of Costa Rica, San Pedro de Montes de Oca 11501, Costa Rica. ${ }^{4}$ Turrialba, Costa Rica. ${ }^{5}$ Present Address: Wageningen University, Hollandseweg 1, 6706 KN Wageningen, The Netherlands.}

\section{Acknowledgements}

We are grateful to the 860 farmers for participating in the survey; Federico Castillo, Juan Manuel Medina, and Jorge Albizúrez for support with field work; Lucia Contreras and Tabare Capitan for data entry and management; Sergio Vilchez-Mendoza for help with data analysis; Kellee Koenig for preparing Fig. 1; Nishina Nambiar for accessing scientific literature, and Vlasova Gonzalez for administrative support. This work was conducted as part of the CASCADE project ('Ecosystem-based Adaptation for Smallholder Subsistence and Coffee Farming Communities in Central America'), which was funded by the International Climate Initiative (IKI) of the German Federal Ministry for the Environment, Nature Conservation, Building and Nuclear Safety (BMUB). BMUB supports this initiative on the basis of a decision adopted by the German Bundestag.

\section{Competing interests}

The authors declare that they have no competing interests.

\section{Availability of data and materials}

The datasets used and/or analyzed during the current study are available from the corresponding author on reasonable request.

\section{Consent for publication}

Not applicable.

\section{Ethics approval and consent to participate}

The household survey underwent a full review process by the Internal Review Committee of Conservation International (approved March 26, 2014). All key personnel completed a Responsible Conduct of Research (RCR) course prior to data collection. Potential participants in the study were invited to participate, provided with information about the use of the data, and formally asked for consent to participate; they were also informed that they could withdraw from the survey at any point.

\section{Funding}

All data collection, data analysis, and write-up of the study were funded by the International Climate Initiative (IKI) of the German Federal Ministry for the Environment, Nature Conservation, Building and Nuclear Safety (BMUB). The funder had no role in the design of the study, collection, analysis, and interpretation of data, or writing of the manuscript.

\section{Publisher's Note}

Springer Nature remains neutral with regard to jurisdictional claims in published maps and institutional affiliations.

Received: 6 March 2018 Accepted: 26 July 2018

Published online: 14 August 2018

\section{References}

1. Vermeulen SJ, Aggarwal PK, Ainslie A, Angelone C, Campbell BM, Challinor AJ, Hansen JW, Ingram JSI, Jarvis A, Kristjanson P, Lau C. Options for support to agriculture and food security under climate change. Environ Sci Policy. 2012. https://doi.org/10.1016/.envsci.2011.09.003.

2. Lipper L, Thornton P, Campbell BM, Baedeker T, Braimoh A, Bwalya M, Caron P, Cattaneo A, Garrity D, Henry K, Hottle R. Climate-smart 
agriculture for food security. Nat Clim Change. 2014. https://doi. org/10.1038/nclimate2437.

3. Lowder SK, Skoet J, Raney T. The number, size, and distribution of farms, smallholder farms, and family farms worldwide. World Dev. 2016. https://doi.org/10.1016/j.worlddev.2015.10.041.

4. Morton JF. The impact of climate change on smallholder and subsistence agriculture. Proc Natl Acad Sci. 2007. https://doi.org/10.1073/ pnas.0701855104.

5. Cohn AS, Newton P, Gil JD, Kuhl L, Samberg L, Ricciardi V, Manly JR, Northrop S. Smallholder agriculture and climate change. Annu Revi Environ Resour. 2017. https://doi.org/10.1146/annurev-environ-10201 6-060946.

6. Holland MB, Shamer SZ, Imbach P, Zamora JC, Medellín C, Leguía E, Donatti Cl, Martínez-Rodríguez MR, Harvey CA. Mapping agriculture and adaptive capacity: applying expert knowledge at the landscape scale. Clim Change. 2017. https://doi.org/10.1007/s10584-016-1810-2.

7. Donatti $\mathrm{Cl}$, Harvey CA, Martinez-Rodriguez MR, Vignola R, Rodriguez CM. Vulnerability ofsmallholder farmers to climate change in Central America and Mexico: current knowledge and research gaps. Clim Dev. 2018. https://doi.org/10.1080/17565529.2018.1442796.

8. Harvey CA, Rakotobe ZL, Rao NS, Dave R, Razafimahatratra H, Rabarijohn RH, Rajaofara H, Mackinnon JL. Extreme vulnerability of smallholder farmers to agricultural risks and climate change in Madagascar. Philos Trans R Soc. 2014. https://doi.org/10.1098/rstb.2013.0089.

9. Castellanos EJ, Tucker C, Eakin H, Morales H, Barrera JF, Diaz R. Assessing the adaptation strategies of farmers facing multiple stressors: lessons from the coffee and global changes project in Mesoamerica. Environ Sci Policy. 2013. https://doi.org/10.1016/j.envsci.2012.07.003.

10. Donatti $\mathrm{Cl}$, Harvey CA, Martinez-Rodriguez MR, Vignola R, Rodriquez CM. What information do policy makers need to develop climate adaptation plans for smallholder farmers? The case of Central America and Mexico. Clim Change. 2017. https://doi.org/10.1007/s1058 4-016-1787-x.

11. Hannah L, Donatti Cl, Harvey CA, Alfaro E, Rodriguez DA, Bouroncle C, Castellanos E, Diaz F, Fung E, Hidalgo HG, Imbach P, Landrum J, Solano AL. Regional modeling of climate change influence on ecosystems and smallholder agriculture in Central America. Clim Change. 2017. https:// doi.org/10.1007/s10584-016-1867-y.

12. PRESANCA, FAO. Centroamérica en Cifras. Datos de Seguridad Alimentaria Nutricional y Agricultura Familiar. 2011. http://www.fao.org/fileadmin/ user_upload/AGRO_Noticias/docs/CentroAm\%C3\%A9ricaEnCifras.pdf. Accessed 10 Oct 2017

13. Hellin J, Schrader K. The case against direct incentives and the search for alternative approaches to better land management in Central America. Agric Ecosyst Environ. 2003. https://doi.org/10.1016/S0167 -8809(03)00149-X

14. Morris KS, Méndez VE, Olson MB. 'Los meses flacos': seasonal food insecurity in a Salvadoran organic coffee cooperative. J Peasant Stud. 2013. https://doi.org/10.1080/03066150.2013.777708.

15. Bacon CM, Sundstrom WA, Stewart IT, Beezer D. Vulnerability to cumulative hazards: coping with the coffee leaf rust outbreak, drought, and food insecurity in Nicaragua. World Dev. 2017. https://doi.org/10.1016/j.world dev.2016.12.025.

16. Eitzinger A, Läderach P, Sonder K, Schmidt A, Sian G, Beebe S, Rodríguez B, Fisher M, Hicks P, Navarrete-Firas C, Nowak A. Tortillas on the roaster: Central America's maize-bean systems and the changing climate. CIAT Policy Brief No. 6. Cali: Centro Internacional de Agricultura Tropical (CIAT); 2012

17. CEPAL (Comisión Económica Para América Latina y el Caribe). El impacto de la caída de los precios de café en el 2001. 2002. http://www.fondo minkachorlavi.org/cafe/docs/cepal2002.pdf. Accessed 1 Oct 2016.

18. Tucker CM, Eakin H, Castellanos EJ. Perceptions of risk and adaptation: coffee producers, market shocks, and extreme weather in Central America and Mexico. Glob Environ Change. 2010. https://doi.org/10.1016/j. gloenvcha.2009.07.006.

19. Altieri MA, Funes-Monzot F, Petersen P. Agroecologically efficient agricultural systems for smallholder farmers: contributions to food sovereignty. Agron Sustain Dev. 2012. https://doi.org/10.1007/s13593-011-0065-6.

20. Gay C, Estrada F, Conde C, Eakin H, Villers L. Potential impacts of climate change on agriculture: a case study of coffee production in
Veracruz, Mexico. Clim Change. 2006. https://doi.org/10.1007/s1058 4-006-9066-xcc.

21. Lin BB. Agroforestry management as an adaptive strategy against potential microclimate extremes in coffee agriculture. Agric For Meteorol. 2007. https://doi.org/10.1016/j.agrformet.2006.12.009.

22. Conde C, Liverman D, Flores M, Ferrer R, Araújo R, Betancourt E, Villarreal G, Gay C. Vulnerability of rainfed maize crops in Mexico to climate change. Clim Res. 1997;9:17-23.

23. Rahn E, Läderach P, Baca M, Cressy C, Schroth G, Malin D, Van Rikxoort H, Shriver J. Climate change adaptation, mitigation and livelihood benefits in coffee production: where are the synergies? Mitig Adapt Strat Glob Change. 2014. https://doi.org/10.1007/s11027-013-9467-x.

24. FAO (Food and Agriculture Organization. Dry corridor-situation report June 2016. 2016. http://www.fao.org/emergencies/resources/docum ents/resources-detail/en/c/422097. Accessed 16 Jun 2017.

25. Philpott SM, Lin BB, Jha S, Brines SJ. A multi scale assessment of hurricane impacts on agricultural landscapes based on land use and topographic features. Agric Ecosyst Environ. 2008. https://doi.org/10.1016/j. agee.2008.04.016

26. Cruz-Bello GM, Eakin H, Morales H, Barrera JF. Linking multi-temporal analysis and community consultation to evaluate the response to the impact of Hurricane Stan in coffee areas of Chiapas, Mexico. Nat Hazards. 2011. https://doi.org/10.1007/s11069-010-9652-0.

27. Eakin H, Benessaiah K, Barrera JF, Cruz-Bello GM, Morales H. Livelihoods and landscapes at the threshold of change: disaster and resilience in a Chiapas coffee community. Reg Environ Change. 2012. https://doi. org/10.1007/s10113-011-0263-4.

28. Ruiz Meza LE. Adaptive capacity of small-scale coffee farmers to climate change impacts in the Soconusco region of Chiapas, Mexico. Clim Dev. 2015. https://doi.org/10.1080/17565529.2014.900472.

29. Haggar J, Schepp K. Coffee and climate change. Desk study: impacts of climate change in four pilot countries of the coffee and climate initiative. 2011. http://www.coffeeandclimate.org/tl_files/Themes/CoffeeAndC limate/Country\%20profiles/0711_Coffee\%20and\%20Climate\%20Cha nge_synthesis\%20report_final.pdf. Accessed 10 Sept 2017.

30. Magrin G, Gay García C, Cruz Choque D, Giménez JC, Moreno AR, Nagy GJ, Nobre C, Villamizar A. Latin America. In: Parry ML, Canziani OF, Palutikof JP, van der Linden PJ, Hanson CE, editors. Climate change 2007: impacts, adaptation and vulnerability, contribution of working group II to the fourth assessment report of the intergovernmental panel on climate change. Cambridge: Cambridge University Press; 2007. p. 581-615.

31. Imbach $P$, Beardsley $M$, Bouroncle $C$, Medellín $C$, Läderach $P$, Hidalgo $H$, Alfaro E, Van Etten J, Allan R, Hemming D, Stone R, Hannah L, Donatti Cl. Climate change, ecosystems and smallholder agriculture: an introduction to the special issue. Clim Change. 2017. https://doi.org/10.1007/s1058 4-017-1920-5.

32. Läderach P, Ramirez-Villegas J, Navarro-Racines C, Zelaya C, Martinez-Valle A, Jarvis A. Climate change adaptation of coffee production in space and time. Clim Change. 2017. https://doi.org/10.1007/s10584-016-1788-9.

33. Avelino J, Cristancho M, Georgiou S, Imbach P, Aguilar L, Benemann G, Läderach P, Anquetil F, Hruska A, Morales C. The coffee rust crises in Colombia and Central America (2008-2013): impacts, plausible causes and proposed solutions. Food Secur. 2015. https://doi.org/10.1007/s1257 $1-015-0446-9$

34. ICO (International Coffee Organization). Report on the outbreak of coffee leaf rust in Central America and action plan to combat the pest. 2013. http://www.ico.org/documents/cy2012-13/ed-2157e-report-clr.pdf. Accessed 01 Sept 2017

35. MARN. Política Nacional de Cambio Climático. 2009. http://www.marn. gob.gt/Multimedios/56.pdf. Accessed 01 Jun 2017.

36. DNCC (Dirección Nacional de Cambio Climático). Plan de Acción de la Estrategia Nacional de Cambio Climático. 2015. http://cambioclimatico cr.com/2012-05-22-19-42-06/estrategia-nacional-de-cambio-climatico. Accessed 01 Oct 2017.

37. Mesa de Trabajo en Cambio Climático de la Secretaría de Agricultura y Ganadería. Estrategia Nacional de Adaptación al Cambio Climático para el sector Agroalimentario de Honduras (2015-2025), versión ejecutiva. Tegucigalpa: Programa de Adaptación al Cambio Climático en el sector forestal (CLIFOR); 2015.

38. Schroth G, Läderach P, Dempewolf J, Philpott S, Haggar J, Eakin H, Castillejos T, Moreno JG, Pinto LS, Hernandez R, Eitzinger A. Towards a climate 
change adaptation strategy for coffee communities and ecosystems in the Sierra Madre de Chiapas, Mexico. Mitig Adapt Strat Glob Change. 2009. https://doi.org/10.1007/s11027-009-9186-5.

39. Baca M, Läderach P, Haggar J, Schroth G, Ovalle O. An integrated framework for assessing vulnerability to climate change and developing adaptation strategies for coffee growing families in Mesoamerica. PLoS ONE. 2015. https://doi.org/10.1371/journal.pone.0088463.

40. Eakin H, Appendini K, Sweeney S, Perales H. Correlates of maize land and livelihood change among maize farming households in Mexico. World Dev. 2015. https://doi.org/10.1016/j.worlddev.2014.12.012.

41. Eakin H. Smallholder maize production and climatic risk: a case study from Mexico. Clim Change. 2000. https://doi.org/10.1023/A:1005628631 627.

42. INEC (Instituto Nacional de Estadística y Censos). Censo Cafetalero: Turrialba y Coto Brus 2003, Valle Central y Valle Central Occidental 2004, y Pérez Zeledón, Tarrazú y Zona Norte 2006. Principales resultados. 1st ed. San José: INEC; 2007.

43. Di Rienzo JD, Casanoves F, Balzarini MG, Gonzalez L, Tablada M, Robledo CW. InfoStat. Córdoba: Universidad Nacional de Córdoba; 2016.

44. Maddison DJ. The perception of and adaptation to climate change in Africa. Policy Research Working Paper 4308. Washington: World Bank; 2007.

45. Deressa TT, Hassan RM, Ringler C. Perception of and adaptation to climate change by farmers in the Nile basin of Ethiopia. J Agric Sci. 2011. https:// doi.org/10.1017/S0021859610000687.

46. Esham M, Garforth C. Agricultural adaptation to climate change: insights from a farming community in Sri Lanka. Mitig Adapt Strat Glob Change. 2013. https://doi.org/10.1007/s11027-012-9374-6.

47. Chengappa PG, Devika CM, Rudragouda CS. Climate variability and mitigation: perceptions and strategies adopted by traditional coffee growers in India. Clim Dev. 2017. https://doi.org/10.1080/17565529.2017.1318740.

48. Hidalgo HG, Alfaro EJ, Quesada-Montano B. Observed (1970-1999) climate variability in Central America using a high-resolution meteorological dataset with implication to climate change studies. Clim Change. 2017. https://doi.org/10.1007/s10584-016-1786-y.

49. Bacon CM, Sundstrom WA, Gómez MEF, Méndez VE, Santos R, Glottis B, Dougherty I. Explaining the 'hungry farmer paradox': smallholders and fair-trade cooperatives navigate seasonality and change in Nicaragua's corn and coffee markets. Glob Environ Change. 2014. https://doi. org/10.1016/j.gloenvcha.2014.02.005.

50. Jaramillo J, Muchugu E, Vega FE, Davis A, Borgemeister C, Chabi-Olaye A. The influence and implications of climate change on coffee berry borer (Hypothenemus hampei) and coffee production in East Africa. PLoS ONE. 2011. https://doi.org/10.1371/journal.pone.0024528.

51. Bryan E, Ringler C, Okoba B, Roncoli C, Silvestri S, Herrero M. Adapting agriculture to climate change in Kenya: household strategies and determinants. J Environ Manag. 2013. https://doi.org/10.1016/j.jenvm an.2012.10.036.

52. Burnham $\mathrm{M}, \mathrm{Ma}$ Z. Linking smallholder farmer climate change adaptation decisions to development. Clim Dev. 2016. https://doi.org/10.1080/17565 529.2015.1067180.

53. Harvey CA, Martínez-Rodríguez MR, Cárdenas JM, Avelino J, Rapidel B, Vignola R, Donatti Cl. The use of Ecosystem-based Adaptation practices by smallholder farmers in Central America. Agric Ecosyst Environ. 2017. https://doi.org/10.1016/j.agee.2017.04.018.
54. Adger WN, Huq S, Brown K, Conway D, Hulme M. Adaptation to climate change in the developing world. Prog Dev Stud. 2003. https://doi. org/10.1191/1464993403ps060oa.

55. Muttarak R, Lutz W. Is education a key to reducing vulnerability to natural disasters and hence unavoidable climate change? Ecol Soc. 2014. https:// doi.org/10.5751/ES-06476-190142.

56. CBD (Convention on Biological Diversity). Connecting biodiversity and climate change mitigation and adaptation: Report of the second ad hoc technical expert group on biodiversity and climate change. CBD Technical Series No. 41. Montreal: Convention on Biological Diversity; 2009.

57. Vignola R, Harvey CA, Bautista-Solis P, Avelino J, Rapidel B, Donatti C, Martínez MR. Ecosystem-based adaptation for smallholder farmers: definitions, opportunities and constraints. Agric Ecosyst Environ. 2015. https //doi.org/10.1016/j.agee.2015.05.013.

58. Hellin J, William LA, Cherrett I. The Quezungual system: an indigenous agroforestry system from western Honduras. Agrofor Syst. 1999:46:228-37.

59. Holt-Giménez E. Measuring farmers' agroecological resistance after Hurricane Mitch in Nicaragua: a case study in participatory, sustainable land management impact monitoring. Agric Ecosyst Environ. 2002. https://doi. org/10.1016/S0167-8809(02)00006-3.

60. Lasco RD, Delfino RJP, Catacutan DC, Simelton ES, Wilson DM. Climate risk adaptation by smallholder farmers: the roles of trees and agroforestry. Curr Opin Environ Sustain. 2014. https://doi.org/10.1016/j.cosus t.2013.11.013.

61. Verchot LV, Van Noordwijk M, Kandji S, Tomich T, Ong C, Albrecht A, Mackensen J, Bantilan C, Anupama KV, Palm C. Climate change: linking adaptation and mitigation through agroforestry. Mitig Adapt Strateg Glob Change. 2007. https://doi.org/10.1007/s11027-007-9105-6.

62. Cerda R, Alline C, Gary C, Tixier P, Harvey CA, Krolczyk L, Mathieu C, Clément $E$, Aubertite JN, Avelino J. Effects of shade, altitude and management on multiple ecosystem services in coffee agroecosystems. Eur J Agron. 2016. https://doi.org/10.1016/j.eja.2016.09.019.

63. Caswell M, Méndez VE, Bacon CM. Food security and smallholder coffee production: current issues and future directions. ARLG Policy Brief\# 1. Burlington: University of Vermont; 2012.

64. Hellin J, Ridaura- López S. Soil and water conservation on Central American hillsides: if more technologies is the answer, what is the question? AIMS Agric Food. 2016. https://doi.org/10.3934/agrfood.2016.2.194.

65. Lin BB. The role of agroforestry in reducing water loss through soil evaporation and crop transpiration in coffee agroecosystems. Agric For Meteorol. 2010. https://doi.org/10.1016/j.agrformet.2009.11.010.

66. Altieri MA, Nicholls $\mathrm{Cl}$, Henao A, Lana MA. Agroecology and the design of climate change-resilient farming systems. Agron Sustain Dev. 2015. https //doi.org/10.1007/s13593-015-0285-2

67. Bacon CM. Confronting the coffee crisis: can fair trade, organic, and specialty coffees reduce small-scale farmer vulnerability in Northern Nicaragua? World Dev. 2005. https://doi.org/10.1016/j.worlddev.2004.10.002.

68. Frank E, Eakin H, López-Carr D. Social identity, perception and motivation in adaptation to climate risk in the coffee sector of Chiapas, Mexico. Glob Environ Change. 2011. https://doi.org/10.1016/j.gloenvcha.2010.11.001.

69. Lin BB. Resilience in agriculture through crop diversification: adaptive management for environmental change. Bioscience. 2011. https://doi. org/10.1525/bio.2011.61.3.4 